\title{
Cracking in historic masonry and surface finishes: Conservation approaches and solutions
}

Received (in revised form): 15th December, 2004

John Edwards DipBldgCons (RICS), MCIOB, MRICS, IHBC

worked as a bricklayer and mason after leaving school and qualified to City and Guilds advanced craft level. Since that time he has worked as a building surveyor, project manager and client. He is a practitioner and also a commissioner of specialist consultancy services. He is a Chartered Building Surveyor and a Chartered Builder. He is currently Cardiff Castle Surveyor to the Fabric and, as a project manager on behalf of Cardiff Castle and Cardiff Council, has overall responsibility for the current $f 8 \mathrm{~m}$ Cardiff Castle conservation project. He is vice chair of the Association for Building Conservation Management and also a course tutor on the Building Conservation postgraduate programme at the University of Reading.

\begin{abstract}
This paper sets out to explain briefly what conservation is and what it means to properly implement it; it also describes the necessary tools to make sure it happens and details why conservation is the right approach. The paper also looks at the technology of solid wall construction, different types of cracks, in terms of their identification, significance and possible treatment. Cardiff Castle is the case study used as a vehicle to describe the implications that cracks can have on the interiors of buildings. The paper is intended to provide an overview of the issues largely from a practical perspective.
\end{abstract}

\section{Keywords:}

masonry, solid walls, defects, repair, conservation

\section{INTRODUCTION}

If one is to practise a conservation approach, then one must understand what conservation means. There are many definitions of what conservation means, but if it is to be practised in a way that is defendable and explainable, then it must be practised in accordance with very ethical, creditable and respected definitions of what conservation really means.

One such definition comes from the Australian Burra Charter where it is defined as: 'All the processes of looking after a place so as to retain its cultural significance' (ICOMOS, 1999). Cultural significance is defined as: 'Aesthetic, historic, scientific or social value to past, present or future

John Edwards Project Manager Conserving Cardiff Castle

County Hall, Room 430, Atlantic Wharf Cardiff $\mathrm{CF}_{10}$ 4UW, UK

Tel: +44 (o) 2920788359

Mobile: 07796440934

Fax: +44 (o) 2920788341 generations' (ICOMOS, 1999). Accordingly, if one is to practise conservation in its true sense, one has to understand the cultural significance of the elements that make up a structure. This paper is not about how one analyses a structure to determine and grade cultural significance, but it is partly about how such information is utilised in order to help make good decisions. 


\section{As well as understanding significance, good conservation practice also means minimum intervention}

\section{UNDERSTANDING SIGNIFICANCE}

If a conservation plan exists for a structure, it will detail and grade the significance of elements and groups of elements that make up that structure. It is this detailed analysis that will help to determine the treatment that historic masonry receives. Conservation plans, of course, will take account of official guidance on the care of historic buildings and monuments. Planning Policy Guidance (PPG) 15 provides some specific guidance for listed buildings and conservation areas, and PPG16 should be referred to for scheduled monuments.

As well as understanding significance, good conservation practice also means minimum intervention. That means only just doing enough, and not too much. This requires judgment based upon a good understanding of significance and all other issues, which could broadly come under the heading of technicalities. The other essential ingredients of good conservation practice are ensuring that wherever practically possible work should be reversible and all work should be recorded.

\section{UNDERSTANDING THE STRUCTURE}

The next major ingredient of understanding concerns construction. Only with an understanding of the design of a structure and how it was built can one fully appreciate the implications of cracks. Masonry and its finishes are made up of various components. Each of these must be considered separately but also as a whole. That means understanding the masonry units, their jointing material, any finishes applied, as well as the overall structural integrity and what cracks mean to the interior of the structure.

Obviously, understanding exactly what the component parts are, and their interaction and compatibility with one another, is essential. It is also important to understand the historical development of the structure and how design and construction along with the change in materials has altered as the structure developed over time. The history of repair is also an important issue to understand. If there is a conservation plan in place, such issues will be detailed within it. In any case, documentary evidence, combined with site analysis and perhaps off-site analysis, will provide the necessary explanation. Any reports on the current state of repair also will be very useful as a starting point.

\section{THE CONCEPT OF MASONRY DESIGN}

Historic masonry is designed to ensure that the structural component parts, that is the masonry units, suffer minimal decay
In general terms, historic masonry is designed to ensure that the structural component parts, that is the masonry units, suffer minimal decay as a result of other parts of the masonry forming a partial sacrificial role. Moisture ingresses into a wall and evaporates via the much softer and porous lime mortar joints. As this happens, soluble salts evaporate to the face of the joint and this is where crystallisation of salts takes place in cycles as conditions change, in general terms, from damp to dry. The salts expand and contract and this expansion and contraction process causes stress within the pore structure of the mortar 
Defects and repairs will be ascertained with due consideration given to knowledge and data on the characteristics of the cracks noted

A survey also should be
undertaken internally in
order to note any
problems related to the
external areas

A survey also should be undertaken internally in problems related to the which results in erosion of the joint face, which, after a period of time, will have to be renewed, that is, repointed. If masonry has render applied, salts will evaporate from the wall to the face of the render, which will in time erode, but the masonry underneath will be protected.

The foregoing illustrates the fundamentals of masonry design, but one must always be ready to encounter situations where these fundamentals have been detrimentally disturbed by poor and inappropriate maintenance. The other fundamental is the tying of the masonry face to the structure of the wall and, indeed, understanding whether the wall is fully bonded or whether it has a core.

\section{THE SURVEY PROCESS}

In undertaking the survey, one should always have a template. This could be a drawing, sketch, photogrammetry, still photographs or rectified photography, depending upon the circumstances and the structure. The survey will involve annotating the template with all defects, including cracks, and will also involve the description of repairs.

Defects and repairs will be ascertained with due consideration given to knowledge and data on the characteristics of the cracks noted. The survey will also consider the historic significance of the masonry. For example, certain types of masonry units deteriorate in a typical fashion for their type. It may be that the form of deterioration may not have any adverse effect on the sustainability of the masonry; however, it may be the case that the most economic solution would be to replace the masonry unit, but the historical significance value would point towards repairing it. This is the type of consideration that has to be made. A survey also should be undertaken internally in order to note any problems related to the external areas.

If there are uncertainties arising out of the survey, then exploratory work in various forms could be undertaken. Sometimes exploratory works are ill advised, however, either due to potentially adverse effects upon the historic significance value, the extent of exploratory works that could be required or because they will be of little use. One could also consider nondestructive surveying techniques such as impulse radar, which would provide an indication of the construction and the extent of voids present.

In general terms, some simple questions should be asked as follows.

- Is the wall fully bonded, or does it have a core?

- What is the thickness of the wall?

- What material is the wall constructed from?

- What are the characteristics of the materials?

- What is the condition of the masonry units?

- What is the condition of the joints?

- What is the state of the overall structural integrity?

- What is the wall protecting on the inside of the building and how effective is this protection? 
One has to determine the type of stone present, its characteristics, inherent problems and whether it is original or replacement

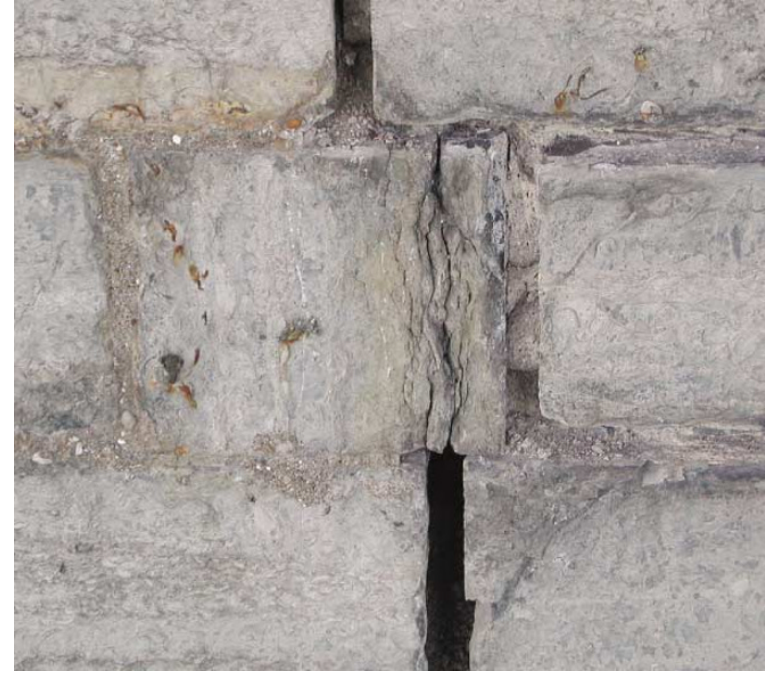

Figure 1: Edge-bedded blue lias

\section{CRACKS IN MASONRY UNITS}

One has to determine the type of stone present, its characteristics, inherent problems and whether it is original or replacement. The make-up of stone is in layers and, wherever possible, masonry units should be laid to ensure that the layers are compressed or supported. This means, for example, that lintels and columns are laid on their natural bed, meaning that the bed runs horizontally. A ledge to a cornice and stone within arches will be laid with the bed running vertically, which is known as edge bedding (see Figure 1). Masonry units should not be laid 'face bedded' (see Figure 2).

Very briefly, this paper will now consider a sample range of different masonry types.

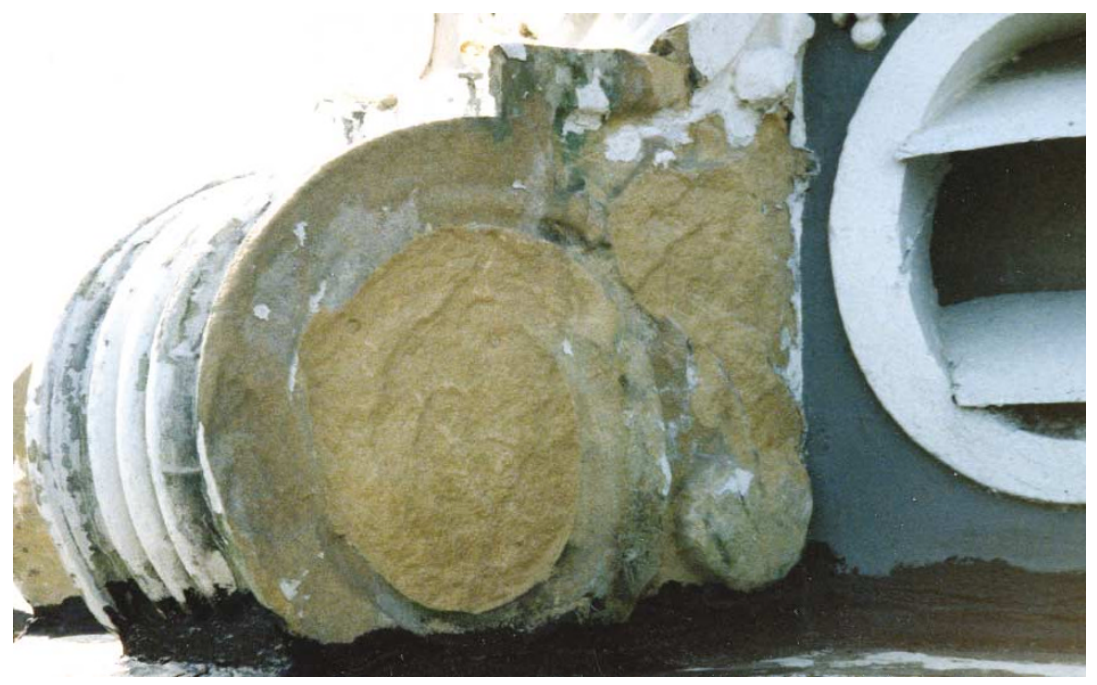

Figure 2: Face-bedded Bath stone 


\section{Characteristics}

\section{Problems}

\section{Remedial works}

\section{Oolitic limestone}

Characteristics include:

— Jurassic age (140-195 million years)

- Calcium carbonate

- Sedimentary

- Usually face stone

- Common varieties include Bath (yellowish) and Portland (white)

- Fine joints.

Problems include:

- Bed direction

- Acid rain forming a calcium sulphate skin. Here the sulphur in rainfall will chemically react with the calcium carbonate within the stone and form a calcium sulphate skin. This hard dense crust is relatively impervious and prevents moisture and salts from reaching the external face of the stone. The recrystallisation of salts therefore will take place underneath this crust. This process can cause the crust to blister, crack and become detached.

Remedial works include:

- Redress face. Whether this is possible will depend on the depth to which the mason has to tool back the stone in order to reach sound stone behind. From a conservation perspective, however, this could be one of the better solutions.

- Stone replacement. This should only be undertaken where absolutely necessary, from a conservation perspective.

- Indented repairs. Replacing small areas within an individual masonry unit ultimately may provide a solution that can be described as minimum intervention, dependent upon the circumstances; however, sometimes this can be disfiguring, which may be an issue if the aesthetics of the masonry are deemed to be highly significant. As always, it will depend upon the building and the circumstances.

- Grouting. This may be one way in which the life of an existing masonry unit may be extended, making it unnecessary to renew.

- Consolidation. Again, this has the same advantage as grouting from a conservation perspective. It is obviously important to steer away from proprietary systems, which are irreversible, if at all possible.

\section{Carboniferous sandstone}

Characteristics include:

- Carboniferous age (280-345 million years)

- Quartz, mica and felspar

- Sedimentary

- Common varieties include Forest of Dean and Pennant

- Ashlar and rubble work. 
Problems include:

- Bed direction

- Contour scaling (see Figure 3). This can be due to pollutants blocking up pores on the face of the masonry unit, which prevent moisture and salts from reaching the external face of the stone. The recrystallisation of salts therefore will take place underneath the surface, causing the face to scale off in contours. This can be exacerbated when joints have been repointed in cement mortars, or where replacement stone has been set in cement mortar.

Remedial works include:

- Redress face. Whether this is possible will depend on the depth to which the mason has to tool back the stone in order to reach sound stone underneath; however, from a conservation perspective, this could be one of the better solutions.

- Grout. If this is the only way in which the life of an existing masonry unit may be extended, making it unnecessary to renew at this stage, then it may be worth considering, but the success of this option needs to be considered carefully.

- Consolidation. Again, this has the same advantage as grouting from a conservation perspective. Given that the traditional method using limewater is not an ideal option with sandstone, however, proprietary systems, which are irreversible, may be the only options available. This is indeed the very last resort, where the only other option is stone replacement.

- Stone replacement. This should only be undertaken where absolutely necessary, from a conservation perspective.

- Indented repairs. Replacing small areas within an individual masonry unit ultimately may provide a solution that practises minimum intervention, dependent upon the circumstances. Sometimes this can be disfiguring, however, which may be an issue, if the aesthetics of the masonry are deemed to be highly significant. As always, it will depend upon the building and the circumstances.

\section{Carboniferous limestone}

Characteristics include:

- Carboniferous age (280-345 million years)

- Sedimentary

- Variation in beds with some poorly cemented

- Can be highly focalised

- Rubble work normally.

Problems include:

- Bed direction

- Lamination along weak beds

- Tendency for cracking into cubes. 


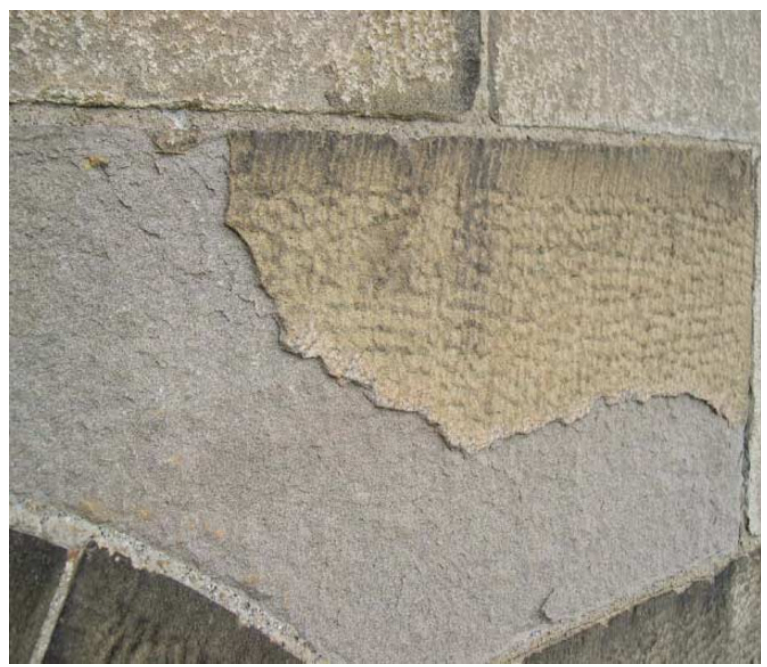

Figure 3: Contour scaling to Forest of Dean

Remedial works include:

- Re-face with new stone. Sometimes, once the outer face has been removed, sound stone will be located behind. This may then provide an opportunity to piece in a new masonry unit on the face, without renewing the complete unit. From a conservation perspective, it is a better solution than complete replacement.

- Grout. This may be one way in which the life of an existing masonry unit may be extended, making it unnecessary to renew.

- Stone replacement. This should only be undertaken where absolutely necessary, from a conservation perspective.

- Consolidate. Again, this has the same advantage as grouting from a conservation perspective. It is obviously important to steer away from proprietary systems, which are irreversible, if at all possible.

- Indented repairs. This is not really a practical option with most stones of this type.

\section{Blue lias (mud stone)}

Characteristics include:

— Jurassic age (140-195 million years)

- Sedimentary

- Fine grained

- Contains a lot of clay

- Often used to make hydraulic lime

- Face stone or rubble.

Problems include:

- Bed direction

- Tendency for fracturing and vertical cracking (see Figure 4)

— Lamination of beds' adjacent joints. 


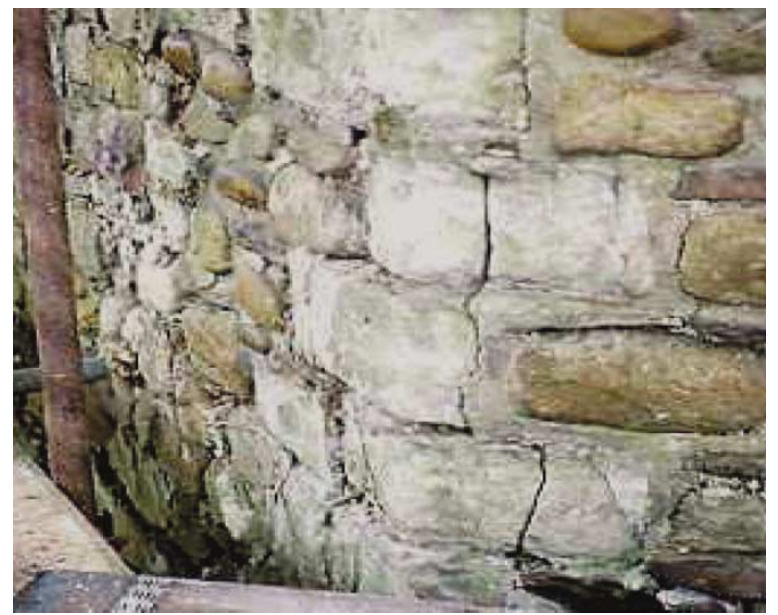

Figure 4: Typical fracturing of blue lias

Remedial works include:

- Remove defective stone and pack up with slate. This is an option where horizontal cracking and lamination occur immediately adjacent to bed joints. Often, a layer of stone will be found in a disintegrated state, reducing the size of the unit. Removal of the defective stone and packing up with slate bedded in mortar is an option that would allow the original masonry unit to remain.

- Pin cracks together with metal ties. There may be a number of ways to pin such vertical cracks. One method is simply to cut horizontal grooves into the face of the stone, into which stainless steel ties can be bedded, followed by pointing in either a mortar that matches the joints or with a natural pigment to match the masonry unit. Pinning cracks in these masonry units should only be necessary in order to sustain structural integrity, where the only other alternative is to replace the stone.

- Grout. This may be one way in which the life of an existing masonry unit may be extended, making it unnecessary to renew. No doubt there will be many occasions where it is thought that the stone simply should be replaced, but if the masonry unit is historically significant enough, then the other option will be grouting.

- Consolidation. This follows the same logic as grouting. Again, this has the same advantage as grouting from a conservation perspective. It is obviously important to steer away from proprietary systems, which are irreversible.

- Stone replacement. This should only be undertaken where absolutely necessary, from a conservation perspective.

- Indented repairs. This is not really a practical option with most stones of this type. 
The most fundamental aspect of the relationship that masonry units have with joints concerns the concept that moisture ingresses into a wall and it evaporates via the joints

\section{One needs to} understand the form of the jointing and understand any inherent weaknesses identified with each form

\section{RELATIONSHIP OF MASONRY UNITS AND JOINTS}

The most fundamental aspect of the relationship that masonry units have with joints concerns the concept that moisture ingresses into a wall and it evaporates via the joints. Over a period of time, the face of the joints will erode due to the recrystallisation process and the wall will need repointing. If the repointing is carried out using a cement mortar, this will inhibit evaporation of moisture from the joints and promote evaporation via the masonry units. The masonry units will therefore decay and eventually may have to be renewed.

\section{Cracks in joints}

One needs to understand the form of the jointing (eg recessed, ribbon, etc) and understand any inherent weaknesses identified with each form. One also needs to understand the materials that the jointing is made from, and whether these have any inherent weaknesses. Whether the joints are original or new is another essential piece of information. This paper will now consider a sample range of joints in different materials.

\section{Cracks in cement mortar joints}

- Hard, brittle and impervious

- Minimise evaporation of moisture from wall via joints

— Eventually lead to pointing becoming detached

- Develop fine hairline cracks permitting ingress of moisture.

\section{Ribbon pointing}

— Protrudes beyond face of masonry units

- Overlaps joints

- Creates a water trap susceptible to erosion of masonry and cracks in pointing.

\section{Movement cracks in joints}

- Thermal and/or moisture movement. Masonry units set and jointed in flexible lime mortar will move, but if inflexible cement mortar is used for pointing it will result in the repointed joints cracking

- Failure of cramps and ties

- Other structural reasons.

Dealing with cracks in joints

- Replace cement mortar pointing with lime mortar

- Remove ribbon pointing leaving either sound joint underneath or pointing flush or recessed. If the ribbon pointing cannot be removed without harming the masonry units, then it may be better to leave alone until such time as it becomes easier to remove

- Replace defective cramps. 


\section{Considering cracks in joints and masonry units}

- Relate joints with units

- Determine whether there are any issues in addition to joints and units.

\section{Structural movement - Loss of bond with core}

Causes can include:

- Tie stones or cramps are either broken, loose or detached

- Rubble core has settled, which may be due to vibration

- Vegetation growth in core.

Detected by:

— Vegetation on masonry growing from cracks

- Bulging walls

- Exploratory work revealing roots in core.

Remedial work can include:

- Remove vegetation on masonry and kill roots

- Remove face masonry in small sections (for example, $1 \mathrm{~m}^{2}$ ) at a time

- Remove vegetation and rebuild as existing.

\section{Cracks in finishes}

The concept of a render applied to a masonry wall is that the render is softer and more porous than the masonry units
The concept of a render applied to a masonry wall is that the render is softer and more porous than the masonry units. Moisture will ingress into the wall and will evaporate via the porous lime render. Salts will recrystallise on the surface of the render, which over time will deteriorate but protect the wall underneath.

Where a lime render has been replaced with a hard dense cement render, the situation will change. Such renders will not cope with this movement and will crack. Also, salts and moisture will not evaporate via the face of the render but will evaporate to the underside of the render, that is, at the interface of the render and the wall. Here, salts will recrystallise, masonry units and the face of joints will erode and the render will lose its bond.

\section{INTERNAL IMPLICATIONS OF CRACKS - CARDIFF CASTLE CASE STUDY}

- What does the external envelope protect?

- What is the vulnerability of what is being protected?

- What is the historic significance of what is being protected?

- Any other issues concerning use and the internal environment to be considered? 


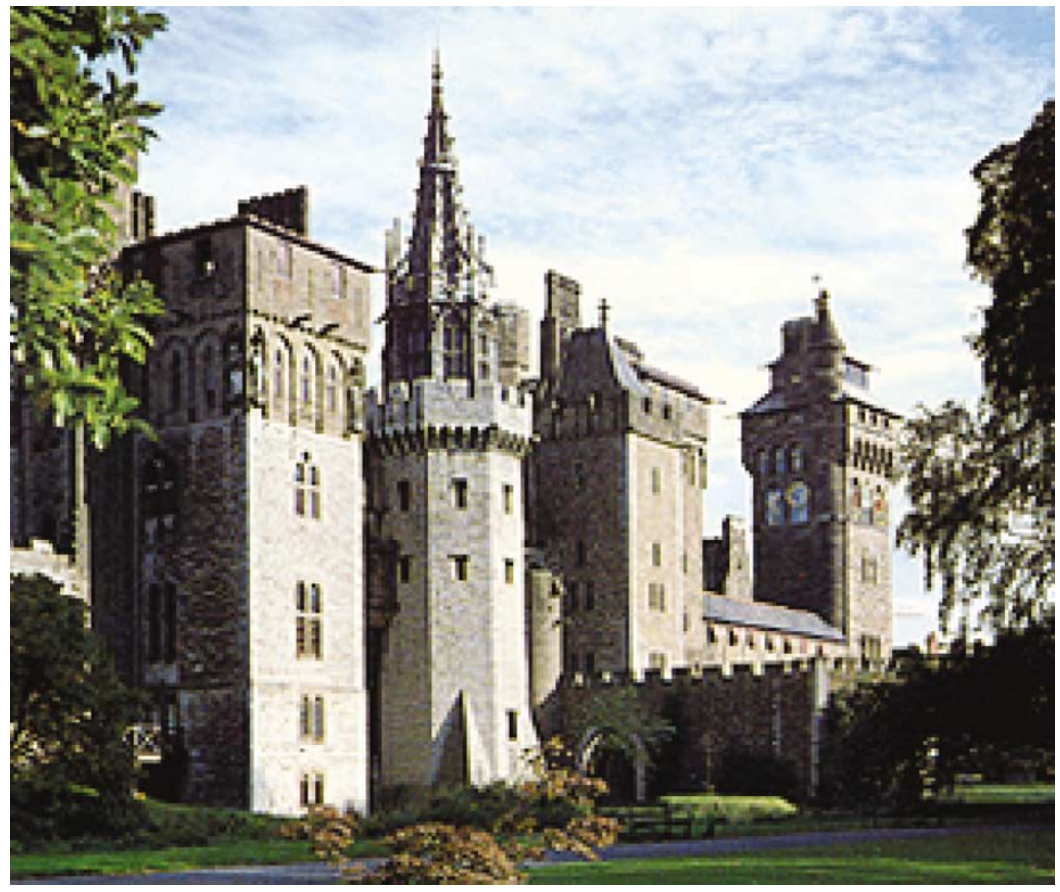

Figure 5: Cardiff Castle House west elevation

- What is the possibility of the cracks increasing the vulnerability of what is being protected?

- Will proposed external work adversely affect the interiors?

The concept of solid wall technology is that moisture ingresses into the wall from the external environment and, before it reaches the internal face, the moisture will dry out via the external face
The concept of solid wall technology is that moisture ingresses into the wall from the external environment and, before it reaches the internal face, the moisture will dry out via the external face. In order for this to work, the wall has to be sufficiently thick. At Cardiff Castle House (see Figure 5) many of the walls are just too thin. The internal decoration is very fragile and susceptible to damage primarily due to the recrystallisation of salts, which can occur even with a very minor change in relative humidity. The decoration is also deemed to be the most significant and important element of Cardiff Castle (see Figure 6).

A multi-disciplined team, led by the Castle Surveyor to the Fabric, undertook a research and analysis programme, primarily in the following four areas: architectural and technical paint research, environmental monitoring, specialist building services engineering and mortar and masonry.

Here the masonry was not considered in isolation. The high degree of importance attached to the interiors meant that the focus of the external work was not automatically to use materials that the structure was originally constructed from, but to use materials that were technically most suitable. The other areas of research and analysis helped the team to focus upon areas of masonry which were allowing detrimental internal environmental conditions to occur.

Where the use of mortars was concerned, this involved preparing a range of mortar mixes that conceivably could be suitable. Various 


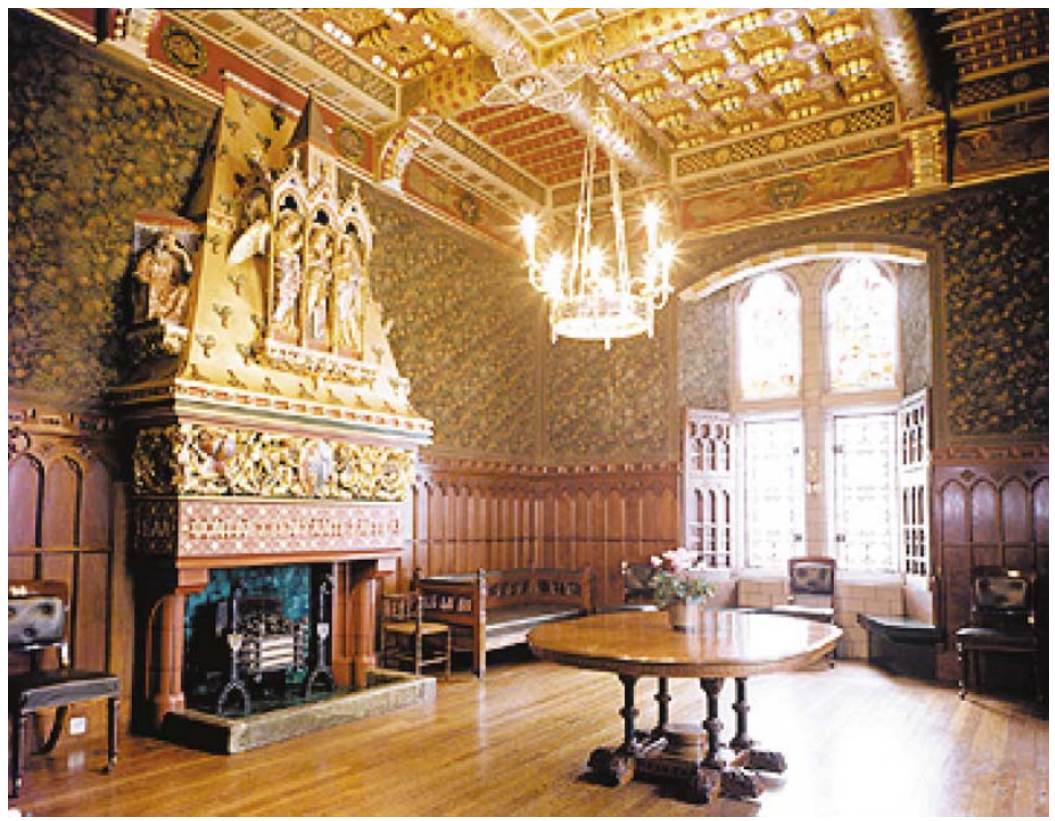

Figure 6: The Small Dining Room, one of the interiors at Cardiff Castle that external masonry has to protect

tests were carried out, including a 'capillary rise' test, which assimilates rainfall and identifies and measures the relative ingress of moisture occurring within a range of mortar mixes. The results shown in Table 1 are a summary of the tests carried out for a duration of $120 \mathrm{~min}$.

The test is intended to indicate which mortar mix is likely to provide the best protection from moisture ingress via rainfall. In conclusion, Mix 8 was found to be most successful. Note that the proportion of magnesium stearate is the same as that within premixed 'eco mortar', produced by St. Astier lime. The tests were carried out by Professor John Ashurst and Catherine Woolfit as part of the Cardiff Castle research and analysis programme.

One has to be cautious,

Even here one has to be cautious, and realise that external works to and realise that external works to masonry can have a detrimental effect on internal finishes, especially when the walls are so slender masonry can have a detrimental effect on internal finishes, especially when the walls are so slender. In winter months, when the internal environment is warm and dry, vapour pressure will be low, thus drawing moisture from masonry work on the outside. One must be especially cautious when grouting walls at this time.

\section{A CONSERVATION APPROACH IS IDEAL FOR ALL OLD BUILDINGS}

Good conservation practice means only proceeding with the utmost knowledge. That means undertaking works which will expand the life span of a structure, often using very traditional techniques and materials. There are many examples to illustrate where a non-conservation approach involving 'modern' materials has been detrimental to the structure. 
Table I: Capillary rise test of 120 minutes' duration on mortar samples

\begin{tabular}{|c|c|c|}
\hline Mix no. & Mortar mix & Rise $(\mathrm{mm})$ \\
\hline I & $\begin{array}{l}\text { I part lime putty (with metastar pozzolan } \\
5 \% \text { of binder weight) and } 2.5 \text { parts sand } \\
\text { (blend) }\end{array}$ & 75 \\
\hline 2 & $\begin{array}{l}\text { I part lime putty (with metastar } \\
\text { pozzolan } 5 \% \text { of binder weight) and } \\
2.5 \text { parts sand and limestone ( } 1: 1 \text { blend) }\end{array}$ & 75 \\
\hline 3 & $\begin{array}{l}\text { I part hydraulic lime NHL2 and } \\
2 \text { parts sand (blend) }\end{array}$ & 75 \\
\hline 4 & $\begin{array}{l}\text { I part hydraulic lime NHL2 and } \\
2 \text { parts sand and limestone ( } 1: 1 \text { blend) }\end{array}$ & 75 \\
\hline 5 & $\begin{array}{l}\text { I part hydraulic lime NHL3.5 and } \\
2 \text { parts sand (blend) }\end{array}$ & 75 \\
\hline 6 & $\begin{array}{l}\text { I part hydraulic lime NHL3.5 and } \\
2 \text { parts sand and limestone ( } 1: 1 \text { blend) }\end{array}$ & 75 \\
\hline 7 & $\begin{array}{l}\text { I part hydraulic lime NHL3.5 } \\
\text { (with } 0.25 \% \text { magnesium stearate } \\
\text { as a proportion of binder weight) } \\
\text { and } 2 \text { parts sand (blend) }\end{array}$ & $40-45$ \\
\hline 8 & $\begin{array}{l}\text { I part hydraulic lime NHL3.5 } \\
\text { (with } 0.25 \% \text { magnesium stearate } \\
\text { as a proportion of binder weight) } \\
\text { and } 2 \text { parts sand and limestone ( } I: I \text { blend) }\end{array}$ & 38 \\
\hline
\end{tabular}

\section{ACKNOWLEDGMENTS}

The author acknowledges the great value of working with numerous other experts over many years. In particular, Professor John Ashurst, Catherine Woolfit, Graham Abrey and Colin Burns have provided very recent input into the author's work at Cardiff Castle.

\section{References and further reading}

BS 8221-1 (2000) 'Code of practice for cleaning and surface repair of buildings: Part 1', British Standards Institution .

Cardiff County Council and Ferguson Mann Architects (2000) 'Cardiff Castle conservation and management plan', unpublished report, not available.

Department of the Environment (1990), Planning Policy Guidance Note 16: Planning Policy Guidance (PPG 16), Department of the Environment.

Department of the Environment and Department of National Heritage (1994a), Planning Policy Guidance Note 15: Planning and the Historic Environment (PIG), Department of the Environment and Department of National Heritage.

Edwards, J. (2002) 'Conserving Cardiff Castle', Journal of Architectural Conservation, 8(1): 7-22.

Edwards, J. (2003) 'Conserving Cardiff Castle — Planning for success', Conservation of Historic Buildings and Their Contents, 80-96, Donhead, Shaftesbury, Dorset.

ICOMOS (1999) The Burra Charter: The Australian ICOMOS Charter for the Conservation of Places of Cultural Significance, ICOMOS.

Ingram Consultancy (2003) 'Mortar and masonry analysis with recommendations for remedial work', unpublished report prepared for Cardiff Council, part of the Cardiff Castle Research and Analysis Programme. Not available.

Kerr, J.S. (1999) Conservation Plans in Action, 9-19, English Heritage.

Leary, E. (1983) The Building Limestones of the British Isles, BRE, Watford.

Leary, E. (1986) The Building Sandstones of the British Isles, BRE, Watford.

Society for the Protection of Ancient Buildings (1979) 'Pointing stone and brick walling', SPAB Information Sheet No. 5, SPAB. 
Society for the Protection of Ancient Buildings (1998) 'The need for old buildings to breathe', SPAB Information Sheet No. 4, SPAB

Society for the Protection of Ancient Buildings (1998) 'An introduction to building times' SPAB Information Sheet No. 9, SPAB.

Society for Protection of Ancient Buildings (1989) 'Roughcast for historic buildings' SPAB Information Sheet No. 11, SPAB. 